Adrian J. Pieters, B.S. (University of Michigan). Botanist in Charge of Seed Laboratory, Department of Agriculture.

Charles L. Pollard, A.B., A.M. (Columbia University). Assistant Curator, Division of Plants, National Museum.

G. Harold Powell, M.S. (Cornell University). Assistant Pomologist, Department of Agriculture.

Percy I. Ricker, M.S. (University of Maine). Scientific Aid in Agrostology, Department of Agriculture.

J. N. Rose, M.A., Ph.D. (Wabash College). Assistant Curator, Division of Plants, National Museum.

Filibert Roth, B.S. (University of Michigan). Chief of Forestry Division, in Charge of U. S. Forestry Reserves, Department of Interior.

Carl S. Scofield, B.S. (University of Minnesota). Expert on Cereals, Department of Agriculture.

Cornelius L. Shear, A.M. (University of Nebraska). Assistant Plant Pathologist, Department of Agriculture.

Erwin F. Smith, B.S., D.Sc. (University of Michigan). Pathologist in Charge of Laboratory of Plant Pathology, Department of Agriculture.

William J. Spillman, M.S. (University of Missouri). Chief Agrostologist, Department of Agriculture.

Dean B. Swingle, B.S. (Kansas Agricultural College), M.S. (University of Wisconsin). Scientific Aid in Laboratory of Plant Pathology, Department of Agriculture.

Walter T. Swingle, M.S. (Kansas Agricultural College). Physiologist in Charge of the Laboratory of Plant Physiology, Department of Agriculture.

William A. Taylor, B.S. (Michigan Agricultural College). Pomologist in Charge of Field Investigations, Department of Agriculture.

Charles O. Townsend, M.S. (University of Michigan), Ph.D. (Leipzig). Plant Pathologist, Department of Agriculture.

J. E. W. Tracy, B.S. (Michigan Agricultural College). Expert Seed Tester, Department of Agriculture.

Rodney H. True, M.S. (University of Wisconsin), Ph.D. (Leipzig). Plant Physiologist, Department of Agriculture.

Merton B. Waite, B.S. (University of Illinois). Pathologist in Charge of Investigations of Diseases of Orchard Fruits, Department of Agriculture.
Herbert J. Webber, M.A. (University of Nebraska), Ph.D. (Washington University). Plant Physiologist in Charge of Laboratory of Plant Breeding, Department of Agriculture.

David White, B.S. (Cornell University). Geologist; Geological Survey.

Milton Whitney, Chief of the Bureau of Soils, Department of Agriculture.

William F. Wight, B.S. (Michigan Agricultural College), M.A. (Stanford University). Assistant, Geographic Botany, Department of Agriculture.

Earley V. Wilcox, Ph.D. (Harvard University). Associate Editor of Experiment Station Record, Department of Agriculture.

Albert F. Woods, M.A. (University of Nebraska). Chief Pathologist and Physiologist, Department of Agriculture.

Total membership, 57.

The plan of organization of the Society provides that, whenever it seems desirable, seminars may be formed for the study and discussion of special topics. Such seminars are to be associated with the Society and to be conducted mainly on the plan of the original Botanical Seminar. Four such seminars have already been formed, namely: (1) Agronomic Seminar, (2) Physiological and Pathological Seminar, (3) Plant Breeding Seminar, (4) Systematic Botanical Seminar.

Botanical activity in Washington is rapidly increasing and the present list of members will probably be greatly enlarged within the next year.

It is not probable that the Society will publish proceedings or issue any papers in the near future; but hereafter reports of the meetings will be furnished to SćIENCE whenever the program is of such a nature as to justify a report.

$$
\begin{gathered}
\text { HERBERT J. WEBBER, } \\
\text { Corresponding Secretary. }
\end{gathered}
$$

\section{THE MOSQUITO CAMPAIGN IN NEW JERSEY.}

There has been much comment in the Press on the above matter since Assembly bill No. 31 was first introduced in the New Jersey Legislature. Though the bill is 
very short, few journals printed it, and when printed it appears that very few read it carefully enough to understand its real purport. The common belief seems to be that for the sum of $\$ 10,000$ the State Entomologist is to destroy all the mosquitoes in the state during the current season. It needs only the most casual aequaintance with the character of the problem to make it obvious that any attempt to such an end would be foredoomed to ridiculous failure; but it was just this misapprehension that is accountable for such opposition as the real scheme met with. The act is so short and its objects are so briefly set out that it is here presented in full.

An Act to Provide for an Investigation aNd Report by the NeW Jersey Agriculturat Experiment Station, upon the Mosquito Problem, in its Relation to the Sanitary, Agricultural AND Other INTerests OF THE State.

Be it enacted by the Senate and General Assembly of the State of New Jersey:

1. That the New Jersey Agricultural Experiment Station be and the same is hereby empowered and directed to investigate and report upon the mosquitoes occurring within the State, their habits, life history, breeding places, relation to malarial and other diseases, the injury caused by them to the agricultural, sanitary and other interests of the State, their natural enemies, and the best methods of lessening, controlling or otherwise diminishing the numbers, injury or detrimental effect upon the agricultural, sanitary and other interests of the State.

2. The sum of ten thousand dollars is hereby appropriated to the New Jersey Agricultural Experiment Station to be applied to and expended for the purposes mentioned in section one of this Act. Such expenditures to be made and accounted for in the same manner as are the other moneys appropriated to said Station.

3. This Act shall take effect immediately.

This act passed the House with little opposition and by a good majority; but in the Senate it encountered active hostility. That body could not be persuaded that there was a serious purpose behind the bill.
Nevertheless it was favorably reported from the committee to which it had been referred, only to find a place in the presiding officer's 'forgotten corner,' whence, it was intended, it should never be removed. But even Senators change sometimes and, for some reason, the bill was resurreeted, brought up for final reading and lost by a tie, changed to a negative vote by one of the advocates of the measure who voted nay that he might move for a reconsideration. The motion to reconsider was made and tabled, leaving a chance for life which was seized in the closing hours of the session.

Public opinion expressed by the newspapers had been and continued to be almost uniformly favorable to the measure and this induced some of the opposition to change their previous negative to affirmative votes.

Nominally therefore the Legislature of the State of New Jersey had passed a bill appropriating $\$ 10,000$ for an investigation and report on the mosquito question and this act was approved by the Governor in due time.

A general State law requires that all sums of money to be paid out by the Comptroller must be included in one of the regular appropriation bills. The regular appropriation bills, however, have been completed and were upon final passage when the mosquito bill passed. No mention of any sum of money for this purpose appears in either the supplementary or the regular appropriation bill passed by the Legislature, consequently there was no money available for the purposes of the act, which, so far as the law-making body is concerned, would have to remain inoperative until a future session should see fit to provide the necessary funds.

The matter was presented to the Governor of the State and he was asked to con- 
sider a request to devote a small sum from an emergency fund, which is under his personal control, that an organization for work might be effected. The Governor had already expressed a favorable interest in the subject and after consideration agreed to assign the sum of one thousand dollars to the purposes mentioned in the bill. It is quite obvious that this sum is totally inadequate to the carrying out of the plan originally formulated, which involved the expenditure of ten times the amount in hand; but considerable preliminary work may be done that will simplify matters when the full sum becomes finally available.

One part of the fund will be devoted to an investigation of the conditions which favor the transmission of malaria in certain districts in the State, and a competent man has been secured for that purpose. $\mathrm{He}$ will be located in a malarial district where Anopheles is abundant and its breeding places numerous. This will afford opportunity for a careful study of the condition under which these mosquitoes areable to carry the organisms causing the disease. The student will be supplied with material from other districts in the State where malaria as an endemic disease is practically unknown. This material will be used in comparison with that collected in the infected locality, and if possible a comparative study of the media in which the larvæ breed will be made.

Another subject that will be taken up by one thoroughly qualified for the work is a study of the food habits of such vertebrates as live in the waters inhabited by mosquito larvæ. It is further expected that collections will be arranged for throughout the State that the mosquito fauna may be thoroughly understood, and the various species locally involved may be intelligently considered.
The general survey of the salt-marsh region, which was contemplated as part of the original plan, will have to be postponed for the present. It will be possible, however, for me to cover the ground in a preliminary way, that I may be fully informed when I am able to put field parties into active service.

Aside from the general work here outlined some of the more common species will be bred in the laboratory in quantities sufficient to allow of experiments with poisonous materials. The application of oil on a large scale has been found somewhat unsatisfactory, and while there is no doubt of its effectiveness in general, there are occasions when its use should be avoided if possible.

This outline of what has been done and what it is expected to do is presented that the scientific world at least should be under no misapprehensions in this matter.

NeW BRUNSWICK,

JoHN B. SмIтH.

May 15, 1902.

\section{SCIENTIFIC BOOKS.}

A University Text-book of Botany. By Douglas Houghton Campbell, Ph.D., Professor of Botany in the Leland Stanford Junior University. New York, The Macmillan Company; London, Macmillan \& Co., Ltd. 1902. All rights reserved. 8vo. Pp. $\mathrm{xv}+579$. With many illustrations.

It has been the pleasant task of the present reviewer on several previous occasions to notice books prepared by Dr. Campbell, each time with increased interest. There was first a little text-book for High Schools-the 'Elements of Structural and Systematic Botany' -which appeared twelve years ago, and justified the reviewer's favorable estimate. Five years later came that admirable book-the 'Structure and Development of Mosses and Ferns'-which has been a handbook of advanced botanists since its publication. This was followed in 1899 by 'Lectures on the Evo- 